\title{
STABILITAS KONSENTRASI GLUKOSA DARAH SIMPAN JANGKA PENDEK DALAM TABUNG BERTEKNOLOGI PEMISAH JEL
}

\section{SHORT TIME STABILITY STUDY OF GLUCOSE IN SERUM SEPARATING TUBE}

\author{
Ayi Furqon ${ }^{1}$, Hilman Nurmukhlis ${ }^{1}$, Sussylawati Kasiman ${ }^{2}$ \\ ${ }^{I}$ Prodi Analis Kesehatan Stikes Jend. Achmad Yani \\ 2 Instalasi Patologi Klinik RSUD Cibabat, Cimahi-Jawa Barat \\ Email: ayifurqon@stikesayani.ac.id \\ ayifurqon@gmail.com
}

Submitted : 10-07-2015

Reviewed : 10-08-2015

Accepted: 25-11-2015

\begin{abstract}
ABSTRAK
Pemeriksaan glukosa darah adalah skrining awal untuk diabetes melitus sehingga pada pemeriksaan ini harus memiliki kualitas hasil pengukuran yang baik. Teknologi Tabung separator memiliki gel yang mengandung Silica Clot Activator dan Polymer Gel yang berfungsi sebagai pemisah antara serum dan sel. Teknologi ini telah lama diterapkan dan digunakan, namun secara efisien tentu saja tabung ini bersifat sekali pakai, di satu sisi tabung gelas dapat digunakan kembali. Untuk itu penting mengetahui seberapa jauh stabilitas konsentrasi glukosa dari kedua kondisi dalam waktu singkat pada suhu ruang $\left(20-26^{\circ} \mathrm{C}\right)$. Penelitian ini menggunakan metode eksperimental yang bertujuan untuk menguji perbedaan kadar glukosa darah pada tabung yang berisi gel separator dan tabung tanpa gel separator yang dikerjakan pada 0 jam, 4 jam, dan 12 jam. Subjek penelitian yaitu 16 orang Mahasiswa Analis Kesehatan Stikes Jenderal Achmad Yani Cimahi dengan sampel berupa serum dari darah vena. Analisis statistik menggunakan uji one way Anova dengan nilai signifikansi 0,05. Dari 16 orang mahasiswa, penurunan konsentrasi glukosa serum masing-masing mulai terjadi pada waktu diatas 4-12 jam yaitu 8,1 mg/dl (p-value $=0,013)$ dan 7,7 mg/dl (p-value 0,012). Persentase penurunan glukosa darah dalam tabung gelas 4 jam pertama $4,75 \%$ dan dalam 12 jam sebesar $13,12 \%$. Pada tabung SST persentase 4 jam pertama dan 12 jam pertama penurunan glukosa serum sebesar 4,33\% dan $12,29 \%$. Kesimpulan, konsentrasi glukosa darah stabil pada suhu ruang sampai 4 jam baik pada teknologi tabung SST maupun tabung gelas.
\end{abstract}

Kata Kunci : glukosa darah, tabung separator gel, glikolisis, sel darah, glukosa serum

\begin{abstract}
Serum glucose level is screening for diabetic patients. Preanalitical factors such as sample preparation and handling will influence the quality of final result of determination. Gel sparation technology used for faster sparation between plasma or serum and blood cells. This technology was applied in clinical laboratory technology in stead of public health laboratory. Requested test of glucose level determination is higher then other analytes. Direct contact of blood cells to serum will reduce availability of glucose in serum due to glycolysis process as well as without additional enzyme inhibitors such as fluoride and without separating cells from serum immediately. Serum separating Tube (SST) contains gel and clot activators, it will work faster than plain tube does to become serum. Main purpose of research, how stability of glucose level between SST tube and plain tube . Experimental steps are preparing fresh blood that is collected from 16 voluntered students, incorporating the glucose oxidase enzymatic assay and quality control. Test performed at immediately, late 4 hours, and very late 12 haours. Statistical method for the time to time analysis, one way Anova is
\end{abstract}


used within significant level 0.05 . From 16 serum (duplicates), glucose serum level was reduced early at $4-12$ hours by $8,1 \mathrm{mg} / \mathrm{dl}(\mathrm{p}$-value $=0.013)$ and $7,7 \mathrm{mg} / \mathrm{dl}(\mathrm{p}$-value 0.012$)$. Percents increases of glucose level within plain tube 4 hours by $4,75 \%$ and within 12 hours by $13,12 \%$. The increased serum glucose level in SST tube were at early 4 hours and 12 hours by 4,33\% and 12,29\% respectively. Conclussion, glucose serum level is in steady at room temperature until 4 hours for both SST Tube as well as plain tube.

Keywords : blood glucose level, serum separator tube, glycolycis, blood cells, serum glucose

\section{PENDAHULUAN}

Pelayanan laboratorium kesehatan atau klinik adalah pelayanan yang dapat menunjang diagnosis penyakit atau monitoring kesembuhan dari pasien. Salah satu parameter kualitas pelayanan di laboratorium adalah penanggulangan beberapa factor kesalahan. Di laboratorium, kesalahan dalam pelayanan dapat dikatagorikan menjadi tiga, yaitu kesalahan pada proses preanalitik (kesalahan identifikasi sampel, kesalahan permintaan, kesalahan dalam teknik flebotomi, pemilihan alat dan bahan). Dari sejumlah 40.490 analisis sampel didapatkan 4,5\% kesalahan. Persentase kesalahan preanalitik sebesar 60-70\%, analitik 10-15\%, pasca analitik 15-18\% (Kitchen, et al., 2008).

Kemajuan produk teknologi dapat menyebabkan hasil lebih cepat, akurat, berpresisi baik pada berbagai kondisi pasien. Factor kesalahan preanalitik menyumbang 60-70\% kesalahan di laboratorium diagnostik, umunya masalah timbul dari persiapan pasien, pengumpulan sampel, pengiriman dan penyimpanan specimen (Lippi, et al., 2011). Pada tahun 1976-an, teknologi tabung berparator diperkenalkan dengan komposisi bahan pengaktif bekuan silica (silica clot activator) dan polimer jel yang terdapat di dalam tabung dalam rangka membantu proses pembekuan darah dan mengurangi waktu sentrifugasi. Jel pemisah digunakan untuk memisahkan serum dari bekuan atau cairan plasma dari sel-sel darah. Dalam hal ini, tabung serum separator tubes (SST) adalah mudah digunakan, memerlukan waktu pemrosesan yang singkat, menghasilkan serum lebih banyak, membatasi bahaya aerosol, memerlukan satu tahap step, menggunakan tabung utama untuk sampling dan satu label (Gigliello \& Kragle, 1975).

Pada penerapan teknologi tabung SST saat sentrifugasi, jel kental ukuran tipis (thixotropic) yang digunakan di dalam tabung berada pada posisi antara sel-sel darah dan lapisan serum (Bush et al., 2001). Posisi jel setelah pemusingan dipengaruhi oleh berbagai karakteristik tabung, seperti berat jenis, tekanan, viskositas, densitas dan bahan tabung. Selain itu dapat pula disebabkan oleh pengaruh suhu, kecepatan sentrifugasi, aselerasi dan deselerasi, penyimpanan dan factor dari pasien sendiri misalnya sedang terapi heparin, hematocrit rendah, tingginya protein plasma dan berat jenis serum/plasma (Spiritus et al., 2003). Karena berat jenis serum/plasma berada pada rentang 1,026 $1,031 \mathrm{~g} / \mathrm{cm}^{3}$ dan berat jenis bekuan berada pada rentang $1,092-1,095 \mathrm{~g} / \mathrm{cm}^{3}$, berat jenis jel idealnya harus diantara 1,03 to $1,09 \mathrm{~g} / \mathrm{cm}^{3}$ (Fatas et al., 2008). Bila berat jenis serum/plasma meningkat dikarenakan hiperproteinemia atau warna radio-contrast, serum tersebut tidak akan terapung diatas jel (Spiritus et al., 2003). Jadi berat jenis lebih penting diperhatikan dibanding factor viskositas (Fatas et al.,2008). Disamping itu, penelitian Faught menunjukkan bahwa ada perbedaan berat jenis jel pemisah yang digunakan pada beberapa tabung SST maupun diantara lot tabung (Faught et al, 2011).

Beberapa penelitian telah menunjukkan bahwa jel ini dapat mempengaruhi konsentrasi analit telah banyak dipublikasi. Pemeriksaan glukosa darah adalah pemeriksaan yang penting di laboratorium klinik terutama bagi pasien diabetes untuk mengendalikan asupan karbohidrat pada uji makan, dan tes toleransi glukosa oral. Telah lama diketahui bahwa metabolism glukosa dalam serum dalam tabung berisi darah mengalami penurunan seiring waktu berjalan. Saat specimen darah belum diuji, proses glikolisis dapat terjadi oleh komponen - komponen seluler di dalamnya dan dapat mengkonsumsi 5\%7\% glukosa terkandung dalam sampel setiap jam (Mikesh \& Bruns, 2008). Penambahan fluorida sebagai inhibitor glycolysis hanya mampu secara efektif digunakan sampai 4 jam penundaan $(\mathrm{Li}$, et al., 2013). 


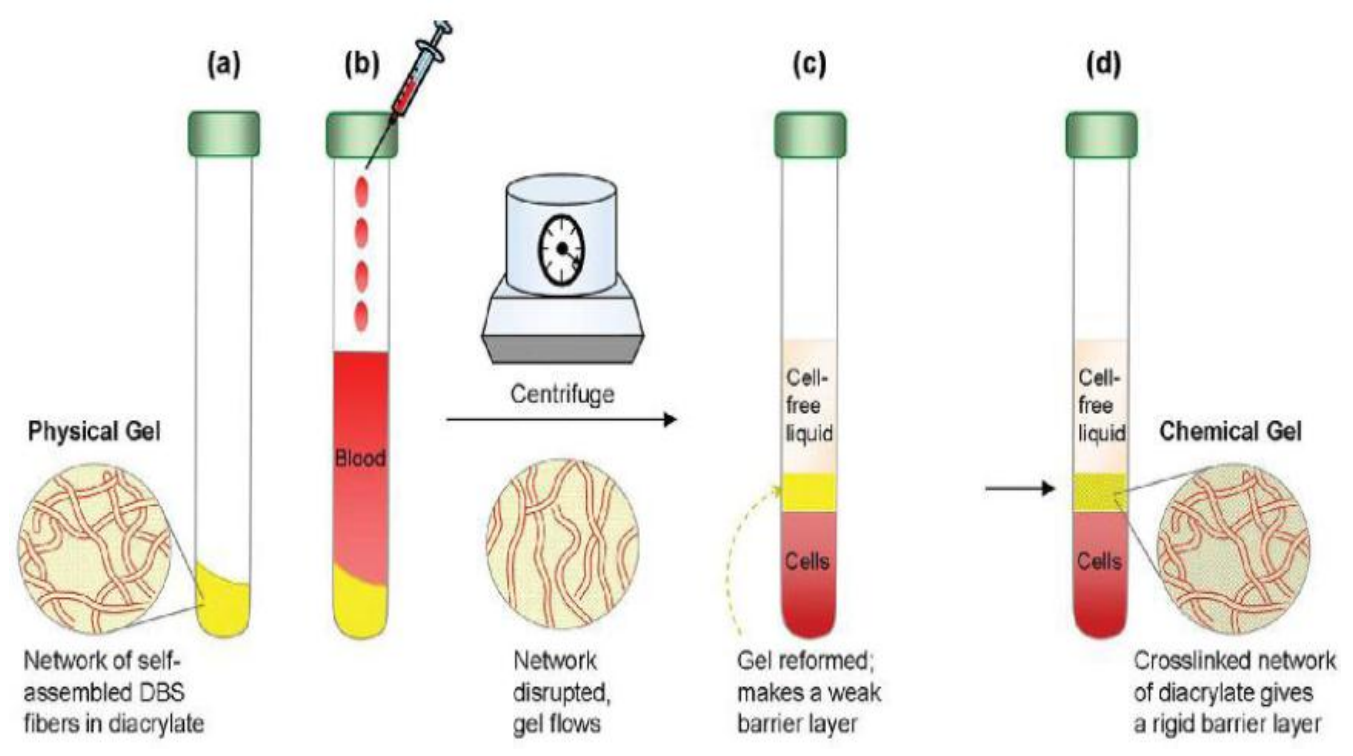

Gambar 1. Skema pemisahan komponen sel - sel dari cairan darah

Sumber: (Kushan et al., 2012)

Bilamana lokasi pasien jauh dari laboratorium atau saat sedang melakukan penelitian masyarakat atau kesehatan masyarakat, yang mana sampel darah yang diperoleh dapat tertunda sebelum analisis laboratorium. Hal ini menjadi penting diteliti seberapa jauh stabilitas glukosa darah terutama di laboratorium klinik sesuai dengan panduan CLSI 88 pada persyaratan akan mengganti tabung gelas menjadi tabung plastik.

\section{METODE PENELITIAN}

Penelitian ini menggunakan metode eksperimental pada 16 sukarelawan mahasiswa yang bersedia diambil darah. Jumlah sampel penelitian dihitung menggunakan rumus Federer: $(\mathrm{t}-1)(\mathrm{n}-1) \geq 15$ (Federer, 1963).

Darah yang telah diambil dibagi dua porsi, porsi tabung gelas dan tabung plastik berpemisah jel, kemudian setelah membeku dipisahkan segera baik pada tabung gelas maupun tabung plastic berpemisah jel. Pengukuran glukosa darah dilakukan menggunakan metode enzimatik trinder yang mengandung enzim glukosa oksidase Spektrum-Diagnostik. Pengukuran dilakukan dengan metode endpoint pada panjang gelombang $546 \mathrm{~nm}$. Kontrol serum menggunakan kontrol level normal dari Humatrol. Pengukuran glukosa dilakukan pada 0 jam, 4 jam dan 12 jam. Analisis statistik menggunakan uji Anova satu arah yang dilanjutkan dengan uji post hoc Bonferoni dengan nilai signifikansi pengambilan keputusan 0,05 . 


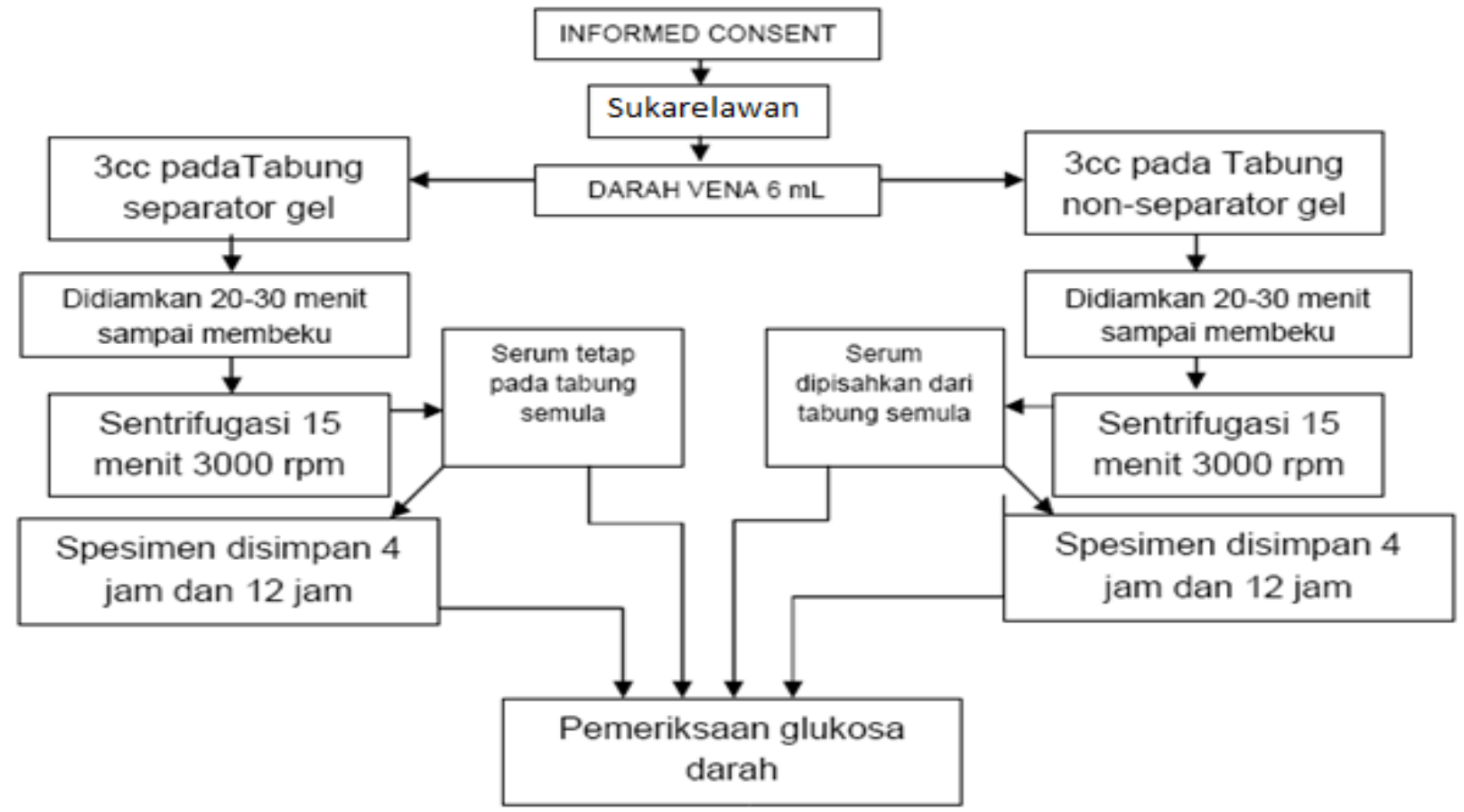

Gambar 2. Skema Kerja Pengukuran Glukosa Darah padaTabung SST

\section{HASIL PENELITIAN}

Pengukuran konsentrasi glukosa kontrol serum diketahui pada 0 jam, 4 jam dan 12 jam secara berurutan adalah 100,8 mg/dl ; 94,5 mg/dl dan 94,9 mg/dl. Keseluruhan nilai kontrol serum berada pada rentang nilai target yaitu antara 79,6 mg/dl sampai $110 \mathrm{mg} / \mathrm{dl}$, sehingga pengukuran pada sampel darah dapat dilakukan. Pengukuran dilakukan secara duplo baik pada tabung gelas maupun tabung plastik berpemisah jel (SST). Berikut adalah hasil pengukuran konsentrasi glukosa serum pada 16 sampel darah:

Tabel I. Analisis univariat konsentrasi glukosa serum

\begin{tabular}{lcc}
\hline Jenis Tabung & $\begin{array}{c}\text { Waktu Simpan } \\
(\mathrm{Jam})\end{array}$ & $\begin{array}{c}\text { Rerata } \pm \text { Simpangan Baku } \\
(\mathrm{mg} / \mathrm{dl})\end{array}$ \\
\hline Gelas & 0 & $96,8 \pm 12,0$ \\
& 4 & $92,2 \pm 11,2(4,75 \%)$ \\
& 12 & $84,1 \pm 9,8(13,12 \%)$ \\
\hline SST & 0 & $96,8 \pm 11,3$ \\
& 4 & $92,6 \pm 9,7(4,33 \%)$ \\
& 12 & $84,9 \pm 10,2(12,29 \%)$ \\
\hline
\end{tabular}

Dari tabel I terlihat bahwa pada awal perlakuan penyimpanan darah dalam kedua jenis tabung menunjukkan rata-rata konsentrasi glukosa yang sama yaitu $96,8 \mathrm{mg} / \mathrm{dl}$. Koefisien varians konsentrasi glukosa serum masing - masing pada tabung gelas maupun tabung SST berturut-turut adalah 12,4\% dan $11,7 \%$. Konsentrasi glukosa dalam serum mulai berkurang dalam 4 jam dan 12 jam penyimpanan baik. Uji normalitas distribusi data dianalisis dengan menggunakan metode Kolmogorov smirnov, diketahui semua nilai $p$-value $>0,05$ dengan demikian data berdistribusi normal dan memenuhi syarat untuk analisis secara inferensial dengan uji anova satu arah. Uji post hoc metode bonferoni diterapkan untuk menelusuri fase waktu mana yang menunjukkan penurunan konsentrasi glukosa yang signifikan, dasar pengambilan keputusan yaitu bila nilai probabilitas p-value lebih kecil dari alfa 0,05, maka penurunan konsentrasi glukosa adalah signifikan. Berikut hasil analisis anova satu arah dan post hoc: 
Tabel II. Analisis bivariate post hoc konsentrasi glukosa serum

\begin{tabular}{cccc}
\hline Jenis Tabung & $\begin{array}{c}\text { Waktu Simpan } \\
(\mathrm{Jam})\end{array}$ & $\begin{array}{c}\text { Selisih Rerata } \\
(\mathrm{mg} / \mathrm{dl})\end{array}$ & $p$-value \\
\hline Gelas* & $0-4$ & 4,6 & 0,294 \\
& $4-12$ & 8,1 & 0,013 \\
& $0-12$ & 12,7 & 0,000 \\
\hline SST $* *$ & $0-4$ & 4,2 & 0,337 \\
& $4-12$ & 7,7 & 0,012 \\
& $0-12$ & 11,9 & 0,000 \\
\hline
\end{tabular}

Hasil uji anova satu arah menghubungkan variabel numerik konsentrasi glukosa serum dari dua jenis perlakuan menurut perubahan blok rentang waktu yang berjalan dengan rentang 4 jam sejak serum diperoleh dari darah vena partisipan. Hasil analisis uji anova menunjukkan nilai p-value $0,000<$ $\alpha 0,05$ berarti ada minimal satu rentang waktu yang menunjukkan perbedaan varians yang bermakna baik pada perlakuan di tabung gelas maupun di tabung SST.

Dengan metode post hoc bonferoni diketahui selisih konsentrasi glukosa serum pada 4 jam pertama penyimpanan dalam tabung gelas dan SST berurutan adalah 4,6 mg/dl dan 4,2 mg/dl. Penurunan konsentrasi glukosa serum masing-masing mulai terjadi pada waktu diatas 4 jam sampai 12 jam yaitu $8,1 \mathrm{mg} / \mathrm{dl}$ (p-value $=0,013<\alpha 0,05)$ dan 7,7 mg/dl $(\mathrm{p}$-value $<\alpha 0,05)$. Persentase penurunan glukosa darah dalam tabung gelas 4 jam pertama antara lain 4,75\%, dalam 12 jam sebesar $13,12 \%$. Pada tabung SST persentase 4 jam pertama dan 12 jam pertama penurunan glukosa serum antara lain sebesar $4,33 \%$ dan $12,29 \%$.

Stabilitas glukosa dalam serum diasumsikan bahwa glukosa yang ada dalam serum akan digunakan oleh sel-sel selain sel darah misalnya oleh adanya kontaminasi mikroba pada serum. Produksi dan manufaktur untuk tabung SST umumnya memiliki berat jenis jel yang relatif bervariasi untuk tiap pabrik sebagaimana penelitian Faught telah menunjukkan bahwa ada perbedaan berat jenis jel pemisah yang digunakan pada beberapa tabung SST maupun diantara lot tabung (Faught et al., 2011). Penggunaan tabung plastic SST umunya bersifat sekali pakai (disposable) sehingga akan menambah biaya pengeluaran untuk pembelian tabung, terlebih untuk penggunaan skala pendek dalam suhu ruang di laboraotrium klinik. Berbeda dengan kepentingan survey seperti pada survey kesehatan masyarakat yang terkendala jarak antara lokasi survey masyarakat dengan lokasi laboratorium analisis (Li, et al., 2013)

Pemeriksaan glukosa darah dalam penelitian ini menunjukkan bahwa penurunan terjadi baik pada tabung gelas maupun tabung SST, penurunan terjadi dalam suhu ruang secara bermakna pada saat diatas 4 jam sampai 12 jam (jangka pendek) penurunan yang signifikan 4,33-12\% kandungan glukosa serum. Jelas hal ini sejalan saat dimana specimen ditunda untuk analisis, proses glikolisis dapat terjadi oleh komponen-komponen seluler di dalamnya dan dapat mengkonsumsi 5\%-7\% glukosa terkandung dalam sampel setiap jam (Mikesh \& Bruns, 2008).

Pemeriksaan ini termasuk pemeriksaan yang memiliki nilai yang memerlukan akurasi dan presisi tinggi agar deteksi dan pengendalian diabetes secara laboratorium baik. Di satu sisi laboratorium untuk menilai efisiensi biaya test dapat mempertimbangkan tabung gelas bilamana pemeriksaan ditunda hanya dalam 4 jam. Penggunaan teknologi tabung SST sekali pakai tampaknya kurang efisien untuk kebutuhan harian dibanding dengan penggunaan tabung gelas yang dapat digunakan secara berulang, namun demikian ada kelebihan dari teknologi tabung SST ini karena cepat dalam memperoleh bahan pemeriksaan serum setelah sentrifugasi dan cukup satu tabung sejak sampling sampai analisis. Banyaknya produk tabung SST yang beredar di Indonesia menjadi perhatian khusus untuk menilai sendiri produk

\section{KESIMPULAN}

Konsentrasi glukosa serum stabil sampai 4 jam pada suhu ruang baik pada tabung SST maupun tabung gelas dan keduanya secara signifikan turun dalam jangka waktu 12 jam. 


\section{DAFTAR PUSTAKA}

Bush, V., Janu, M., Bathur, F., Wells, A., \& Dasgupta, A. (2001). Comparison of BD Vacutainer SST plus tubes and BD SST II plus tubes for common analytes. Clin Chem 2001;306:139-43., 139143.

Fatas, M., Franquelo, P., \& Franquelo, R. (2008). Anomalous flotation of separator gel: density or viscosity? Clin Chem, 771-772.

Faught, R., Marshall, J., \& Bornhorst, J. (2011). Solution densities and estimated total protein contents associated with inappropriate floatation of separator gel in different blood collection tubes. Arch Pathol Lab Med, 135:1081-1084.

Federer, W. (1963). Experimental Design Theory and Application. Oxford: Oxford and Lbh Publish Hinco.

Gigliello, J., \& Kragle, H. (1975, November). Patent No. No. 3,920,549. U.S.

Kitchen, S., Olson, J., \& Preston, F. (2008). Sample Integrity and Preanalytical Variables. In D. Adcock, Quality in Laboratory Hemostasis and Trombosis (p. Ch4). Oxfor: Wiley-Blackwell.

Kushan, S., Emerson, J., \& Raghavan, S. (2012). A New Method for Centrifugal Sparation of Blood Components: Creating a Rigid Barrier Between Density Stratified Layer Using a UV-curabele Thixotropic Gel. The Royal Society of Chemistry, 2378-2382.

Li, G., Cabanero, M., Wang, Z., Wang, H., Huang, T., Alexis, H., et al. (2013). Comparison of glucose determinations on blood samples collected in three types of tubes. Ann Clin Lab Sci., 43(3), 278-84.

Lippi G, C. J., Church, S., Dazzi, P., Fontana, R., \& Giavarina, D. (2011). Preanalytical quality improvement: from dream to reality. Clin Chem Lab Med. 2011;49:1113-26, 49, 1113-26.

Mikesh, L., \& Bruns, D. (2008). Stabilization of glucose in blood specimens: mechanism of delay in fluoride inhibition of glycolysis. Clinical Chemistry, 54(5), 930-932.

Spiritus, T., Zaman, Z., \& Desmet, W. (2003). Iodinated contrast media interfere with gel barrier formation in plasma and serum separator tubes. Clin Chem, 1187-1189. 